\title{
Cefteram Pivoxil
}

National Cancer Institute

\section{Source}

National Cancer Institute. Cefteram Pivoxil. NCI Thesaurus. Code C98230.

The pivalate ester prodrug of cefteram, a semi-synthetic, broad-spectrum, thirdgeneration cephalosporin with antibacterial activity. After oral administration of cefteram pivoxil, the ester bond is cleaved, releasing active cefteram. 